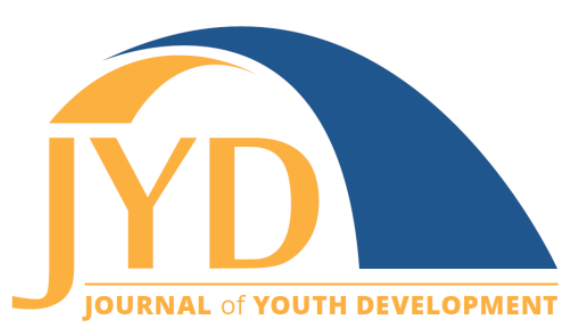

http://jyd. pitt. edu/ | Vol. 13 Issue 3 DOI 10.5195/jyd.2018.678 | ISSN 2325-4017 (online)

\title{
On the Intersection of Health, Well-Being, and Youth Development
}

\author{
Mary Elizabeth Arnold \\ Oregon State University \\ mary.arnold@oregonstate.edu
}

Theresa M. Ferrari

The Ohio State University

ferrari.8@osu.edu

\section{Abstract}

This introduction sets forth forth the thinking that guided the journal's special issue on youth health and well-being. Three main points provide the foundation: (a) that youth development is predicated on a strengths-based approach, (b) that an ecological approach to youth health is essential for real and lasting change, and (c) that the larger intent of youth development is encompassed in increasing youth wellbeing, of which youth health is a key component. The guest editors provide an overview of the articles included in the special issue. The articles highlight different settings, describe the processes involved in developing programs, and address organizations' efforts to enhance youth health and well-being. The reader will also find resources and models that are suitable for use across youth development settings.

Key words: health, well-being, social ecological model, positive youth development

\section{Introduction}

The positive youth development approach examines child and adolescent development from a strengths-based, rather than a deficit-based, lens (Pittman, Irby, Tolman, Yohalem, \& Ferber, 2003). This strength-based focus begins with the premise that all youth have strengths and assets upon which organizations can capitalize and enhance through supports, opportunities, programs, and services that promote positive development (Caldwell \& Witt, 2018). High quality youth development programs include three key elements: fostering positive youth-adult relationships, providing skill-building opportunities, and engaging participants in meaningful

(c) $\mathbf{E Y}$ New articles in this journal are licensed under a Creative Commons Attribution 4.0 License. This journal is published by the University Library System, University of Pittsburgh and is cosponsored by the University of Pittsburgh Press. The Journal of Youth Development is the official peer-reviewed publication of the National Association of Extension 4-H Agents and the National AfterSchool Association. 
roles and leadership opportunities (Roth \& Brooks-Gunn, 2016). Furthermore, this approach recognizes that youth development takes place across the ecological spectrum, as the individual, family, organizational, and societal contexts in which young people live are at work individually and collectively to promote, or hinder, healthy development (Blum, Bastos, Kabiru, \& Le, 2012; Park, 2004; Raphael, 2013). A youth development approach is highly adaptable, because as Moore (2017) notes, "it is not a particular program or curriculum but a set of practices designed to achieve one or more positive outcomes" (p. 1175).

Across the field of youth development, programs have focused heavily on improving youth health through the adoption of healthy lifestyle practices (Agans, Champine, Johnson, Erickson, \& Yalin, 2015). From nutrition, physical activity, safety, substance use, and mental health, the goal has been to increase knowledge, skills, aspirations, and positive attitudes in order to encourage youth to adopt healthful practices that promote lifelong health. This focus is important because healthful practices adopted by youth play a critical role in the prevention of chronic diseases in adulthood (Raphael, 2013; Sawyer et al., 2012). To achieve a real and lasting impact on youth health, however, the focus cannot be on the individual alone. It is incumbent on youth development professionals to also consider the variety of forces at work at all levels of the social ecology (Merzel \& D'Affilitti, 2003), and to give particular emphasis to translating research into organizational policies and practices to promote youth health.

As emphasized in the World Health Organization's (2002) definition, health is so much more than one's physical health and the absence of disease. Similarly, the youth development approach acknowledges that "problem free is not fully prepared" (Pittman et al., 2003, p. 6), and youth are not simply passive program participants, they are active agents in shaping their own development (Lounsbury \& Mitchell, 2009). From the outset of planning this special issue on youth health and well-being, our intent was to highlight a broad array of topics as well as the connections between health and the greater overall goal of developing youth to be competent, confident, caring, connected, and contributing citizens. We wanted to emphasize a holistic approach to the development of a healthy, happy young person who enjoys life, feels hope and optimism about the future, and possesses the supports and skills necessary to navigate the journey to adulthood successfully (Caldwell \& Witt, 2018).

Research shows that well-being is connected to one's sense of satisfaction with life (Park, 2004) and life satisfaction is positively correlated with physical health and the healthy behaviors that promote it (Grant, Wardle, \& Steptoe, 2009; Proctor, Linley, \& Maltby, 2009). In addition, high life satisfaction is negatively correlated with behaviors that jeopardize health (Zullig, Valois, 
Health, Well-Being, and Youth Development

Huebner, Oeltmann, \& Drane, 2001). Programs that promote civic participation and youth activism "help young people find ways to contribute to their communities, create social change, and promote a sense that they matter" (Ballard \& Ozer, 2016, p. 231). Because they promote a sense of purpose, identity development, and empowerment and develop social capital and connections to others, these experiences are potential pathways to health and well-being. Therefore, the promotion of health behaviors within the context of youth development programs should always consider the impact of health on youth well-being, and the connection of well-being to life satisfaction as the pathway through which youth health is ultimately promoted.

Equally important to focusing on well-being in youth development programs is the need to approach youth health from a systems-level, social ecological perspective (Golden, McLeroy, Green, Earp, \& Lieberman, 2015; McLeroy, Bibeau, Steckler, \& Glanz, 1988; Richard, Gauvin, \& Raine, 2011; Sallis, \& Owen, 2015; Stokols, 1996), which makes youth development compatible with a public health approach (Birkhead, Riser, Mesler, Tallon, \& Klein, 2006). An ecological perspective is critical to understanding youth health concerns, especially when considering the health disparities in access to resources and services that are present across the spectrum (Blum et al., 2012). Youth development theory is based on the mutual interactions of a young person with his or her environments, which result in adaptive developmental regulations that promote youth development (Lerner, Dowling, \& Anderson, 2003; Lerner et al., 2011). The multiple contexts of youth experience form the ecological web that promotes positive development. Youth satisfaction with family and peer relationships is connected to life satisfaction, a finding that holds true across cultures (Park, 2004). Additionally, participation in high-quality, appropriately structured out-of-school time activities is connected to youth life satisfaction (Proctor \& Linley, 2014), and it can even provide a buffering effect for youth who are struggling with family relationships (Mahoney \& Stattin, 2001). Furthermore, and consistent with best practices in youth development, the support provided by non-parental adults in these activities is a critical driver of supporting youth, protecting youth from poor health-related outcomes, and promoting positive youth development (Sieving et al., 2016). Finally, the important role that communities play in affecting youth health is increasingly apparent (Ballard \& Leonard, 2016).

With these perspectives in mind, we organized the articles in this special issue around the social ecological model. The articles highlight different settings, describe the processes involved in developing and evaluating programs (sometimes referred to as the "black box"; Yohalem, \& Wilson-Ahlstrom, 2010), and address organizations' efforts to enhance youth health and well- 
Health, Well-Being, and Youth Development

being. The reader will also find resources and models that are suitable for use across youth development settings.

\section{Teens as Teachers and Agents of Change}

The shift in focus to viewing youth as resources has led to an emphasis in actively involving them in community programs in multiple ways (Wong, Zimmerman, \& Parker, 2010). Teens are interested in health and have ideas for taking action (Brown, Braun, \& Leatherman, 2015). One notable model is that of engaging teens as teachers and ambassadors, an approach that has the dual effect of increasing the teens' own healthy habits, while at the same time providing a structured, scaffolded environment for them to gain leadership and teaching skills as they serve as role models for younger youth (Arnold et al., 2016; Ferrari, in press). Bolshakova and her colleagues describe the development and use of a logic model that guided the implementation of a teens-as-teachers program in school gardens in California. Ross and Connors describe how forming an effective youth-adult partnership improved access to mental health support services in Worcester, Massachusetts, a model that has been sustained for more than 15 years. Weybright and her colleagues explore the positive outcomes achieved in a teens-as-teachers program focused on nutrition education and provide recommendations for effective practice with teen teachers. These articles have broad applicability beyond their subject matter, as they focus on the processes involved, rather than just the content of the programs.

\section{Parents and Families, Schools, and Out-of-School Programs}

Kumpfer and Alvarado (2003) contend that "effective parenting is the most powerful way to reduce adolescent problem behaviors" (p. 457). Two articles in this issue provide examples of programs designed to increase family functioning in support of youth health. Hurtado, Fife, Svetaz, and Allen describe a program to assist immigrant parents and youth as they navigate the complexities of multicultural parenting values and practices, with a goal of preventing tobacco and other substance use. Baker-Tingey, Powell, and Powell describe a program for parents and children to prevent domestic violence. These programs are research based and grounded in community needs, and in turn, they inform best practices.

Out-of-school time is a key environment for promoting positive youth development in general (Smith, Witherspoon, \& Osgood, 2017), as well as for promoting health (Beets, Webster, Saunders, \& Huberty, 2013; Folta et al., 2015). Some state and national organizations have developed health-related policies, for example, regarding healthy eating and physical activity in 
after-school programs (Beets, Tilley, Kim, \& Webster, 2011). Ivy and her co-authors present lessons learned in an after-school program to build personal and social responsibility through a university-school partnership with pre-service physical education teachers. Other articles consider the contexts of youth sports (Hemphill, Janke, Gordon, \& Farrar) and 4-H (BakerTingey, Powell, \& Powell; Bolshakova et al.; Peterson, Downey, \& Leatherman; Taylor-Winney, Giordono, Lesmeister, Fenn, \& Krahn; Weybright, Diaz Martinez, Varella, Deen, \& Wright), the nation's largest youth development program (National 4-H Council, n.d.). The importance of partnerships is a theme evident in many of these articles.

\section{Organizational Efforts}

Schools serve as a major source of influence during children's critical developmental years. Research supports the connection between student health and learning (Michael, Merlo, Basch, Wentzel, \& Wechsler, 2015), thus schools are a logical setting to implement health programs and policies. In their article, Centeio and her colleagues describe the process of adopting school health policies as a critical step for sustaining health-related changes in schools.

It is important that an organization's practices align with its values, but that is not always the case (Economos et al., 2017; Franck, Donaldson, Toman, \& Moody, 2014). Taylor-Winney et al. share the results of their assessment of the practices for the inclusion of youth with disabilities in one state's 4-H program. Peterson and her colleagues provide a national review of curriculum used across the 4-H organization to promote health. Such studies are useful in identifying gaps between desired and actual states and can inform future professional development efforts. These articles also may prove useful as organizations continue to examine their practices and develop guidelines, standards, and polices that promote health.

\section{Models and Resources for Practice}

Models are useful for guiding practice, planning evaluation, and improving program quality (Arnold \& Silliman, 2017). Hemphill et al. share a model for restorative youth sports, which addresses the importance of social interaction skills for youth in sport-based youth development programs. Novick and her colleagues share the Adolescent Health: Think Act Grow (TAG) model and related resources for improving youth health from the U.S. Department of Health and Human Services. Palmer and her colleagues share a program model and online tool for assessing youth status in obesity prevention programs in order to direct program materials and support to the areas of greatest need for change. 
Included in this issue are reviews of four resources available for practitioners to use in their efforts to address youth health. Kingery provides an overview of the County Health Rankings and Roadmaps, which is based on a population health model and includes statistics (the ranking) and suggestions for taking action to improve the well-being of youth and communities (the roadmaps). Ferrari reviews YA4-H! Youth Advocates for Health, a curriculum for engaging youth in participatory action research designed to support youth and their adult partners in examining health concerns in their communities. Brody and Gunter share the Balanced Energy Physical Activity kit that supports fun and easy ways to increase physical activity in classrooms or other group settings. Wong and her colleagues share WAVE Ripples for Change: Obesity Prevention in Active Youth, a new evidence-based curriculum for teaching sports-related nutrition with youth athletes.

\section{Thoughts and Reflections}

We began this introduction with three main points: that a strengths-based approach is a foundation for youth development programs, that an ecological approach to youth health is essential for real and lasting change, and that the larger intent of youth development is encompassed in increasing youth well-being, which is related to overall youth health. The two articles that bookend the issue illustrate two additional considerations for improving youth health and well-being: (a) encouraging professional development to improve youth workers' ability to promote youth health and advocacy and (b) developing partnerships to address youth health at the community level, which includes addressing the health inequities that exist for youth across neighborhoods, communities, race, and socio-economic indicators.

We solicited these two articles to highlight the movement from programs that focus on individual behavior change interventions to the broader ecological context that is necessary to sustain youth health beyond individual programming efforts. As well, there is rising interest in youth advocacy as a promising strategy for addressing health issues (Millstein \& Sallis, 2011). In their thought leader article, Toomey and her colleagues from Cooperative Extension's Positive Youth Development for Health team explore the role of youth workers in building their competency to facilitate youth health advocacy. In their closing piece, Rodgers and Vinluan describe a partnership with Cooperative Extension and the Robert Wood Johnson Foundation that engages youth as advocates serving on community councils that are being created to improve community health. Many factors will determine an organization's readiness for implementing such health-related changes (Smathers et al., 2018). Simply having policies is not 
Health, Well-Being, and Youth Development

enough; there are often barriers to their adoption and issues of accountability and compliance. Whether volunteers, frontline staff, or an organization's national leaders, all will share a role in moving forward.

As we draw our work to a close, we are grateful to the authors who worked so diligently to prepare the articles for this issue. We were delighted and honored to work with each one and deeply appreciate the generosity and patience that we received in response to the feedback and editing requests we made. It is our hope that this special issue will provoke additional thinking about how health is promoted in the context of community youth development, and that this issue will serve as a catalyst and resource for even more successful practice in the years to come. Working together, we can create a healthier future-with and for youth.

\section{References}

Agans, J. P., Champine, R. B., Johnson, S. K., Erickson, K., \& Yalin, C. (2015). Promoting healthy lifestyles through youth activities participation: Lessons from the research. In E. P. Bowers, G. J. Geldhof, S. K. Johnson, L. J. Hilliard, R. M. Hershberg, J. V. Lerner, \& R. M. Lerner (Eds.), Promoting positive youth development: Lessons from the 4-H study (pp. 137-158). New York: Springer.

Arnold, M. E., Flesch, J. M., Ashton, C., Black, L., Brody, B., Hosty, M., \& Northway, S. (2016). YA4-H! Youth advocates for health: Impact of a 4-H teens-as-teachers program. Journal of Extension, 54(6), Article 6RIB5. Retrieved from https://www.joe.org/joe/2016december/rb5.php

Arnold, M. E., \& Silliman, B. (2017). From theory to practice: A critical review of positive youth development program frameworks. Journal of Youth Development, 12(2), 1-20. doi: 10.5195/jyd.2017.17

Ballard, P. J., \& Leonard, S. S. (2016). Engaging youth in communities: A framework for promoting adolescent and community health. Journal of Epidemiology and Community Health, 70(2), 202206. doi: 10.1136/jech-2015-206110

Ballard, P. J., \& Ozer, E. J. (2016). The implications of youth activism for health and well-being. In J. Conner \& S. M. Rosen (Eds.), Contemporary youth activism: Advancing social justice in the United States (pp. 223-243). Santa Barbara, CA: Praeger.

Beets, M. W., Tilley, F., Kim, Y., \& Webster, C. (2011). Nutritional policies and standards for snacks served in after-school programmes: A review. Public Health Nutrition, 14(10), 1882-1890. doi: 10.1017/S1368980011001145 
Beets, M. W., Webster, C., Saunders, R., \& Huberty, J. L. (2013). Translating policies into practice: A framework to prevent childhood obesity in afterschool programs. Health Promotion Practice, 14(2), 228-237. doi: 10.1177/1524839912446320

Birkhead, G., Riser, M. H., Mesler, K., Tallon, T. C., \& Klein, S. J. (2006). Youth development is a public health approach. Journal of Public Health Management and Practice, 12(Supplement 6), S1-S3.

Blum, R. W., Bastos, F. I. P. M., Kabiru, C. W., \& Le, L. C. (2012). Adolescent health in the $21^{\text {st }}$ century. The Lancet, 370, 1567-1568. doi: 10.1016/S0140-6736(12)60407-3

Brown, V., Braun, B., \& Leatherman, J. (2015). Bold ideas for the $4^{\text {th }} \mathrm{H}$ in 4-H: Teen identified concerns and actions. Journal of Youth Development, 10(1), 151001FA006. doi: 10.5195/jyd.2015.421

Caldwell, L. L., \& Witt, P. A. (2018). Ten principles of youth development. In P. A. Witt, \& L. L. Caldwell (Eds.), Youth development: Principles and practices in out-of-school time settings ( $\left.2^{\text {nd }} \mathrm{ed}.\right)$. Urbana, IL: Sagamore.

Economos, C. D., Anzman-Frasca, S., Koomas, A. H., Chan, G., Folta, S. C., Heck, J., . . Sacheck, J. M. (2017). Snacks, beverages, and physical activity during volunteer-led out-of-school time programs: A cross-sectional analysis. BMC Public Health, 17, 125. doi: 10.1186/s12889-0174040-2

Ferrari, T. M. (in press). 4-H health ambassador programs: A survey of organizational and programmatic aspects. Journal of Extension.

Folta, S. C., Koomas, A., Metayer, N., Fullerton, K. J., Hubbard, K. L., Anzman-Frasca, S., . . Economos, C. (2015). Engaging stakeholders from volunteer-led out-of-school time programs in the dissemination of guiding principles for healthy snacking and physical activity. Preventing Chronic Disease, 12, 150270. doi: 10.5888/pcd12.150270

Franck, K. L., Donaldson, J. L., Toman, J., \& Moody, T. (2014). Moving beyond the program: Incorporating health living behaviors throughout 4-H. Journal of Extension, 52(4), 4COM2. Retrieved from https://joe.org/joe/2014august/comm2.php

Grant, N., Wardle, J., \& Steptoe, A. (2009). The relationship between life satisfaction and health behavior: A cross-cultural study of young adults. International Journal of Behavioral Medicine, 16, 259-268. doi: 10.1007/s12529-009-9032-x

Golden, S. D., McLeroy, K. R., Green, L. W., Earp, J. L., \& Lieberman, L. D. (2015). Upending the social ecological model to guide health promotion efforts toward policy and environment change. Health Education and Behavior, 42(1S), 8S-14S. doi: 10.1177/1090198115575098

Kumpfer, K. L., \& Alvarado, R. (2003). Family strengthening approaches for the prevention of youth problem behaviors. American Psychologist, 58(6/7), 457-465. doi: 10.1037/0003-066X.58.67.457 
Journal of Youth Development | http://jyd.pitt.edu/ | Vol. 13 Issue 3 DOI 10.5195/jyd.2018.678 Health, Well-Being, and Youth Development

Lerner, R. M., Dowling, E. M., \& Anderson, P. M. (2003). Positive youth development: Thriving as the basis of personhood and civil society. Applied Developmental Science, 7, 172-180. doi: 10.1207/S1532480XADS0703_8

Lerner, R. M., Lerner, J. V., Lewin-Bizan, S., Bowers, E. P., Boyd, M. J., Meuller, M. K., . . Napolitano, C. M. (2011). Positive youth development: Processes, programs, and problematics. Journal of Youth Development, 6(3), 110603FA003. doi: 10.5195/jyd.2011.174

Lounsbury, D. W., \& Mitchell, S. G. (2009). Introduction to the special issue on social ecological approaches to community health research and action. American Journal of Community Psychology, 44, 213-220. doi: 10.1007/s10464-009-9266-4

Mahoney, J. L., \& Stattin, H. (2001). Leisure activities and adolescent anti-social behavior: The role of structure and social context. Journal of Adolescence, 23(2), 113-127. doi: 10.1006/jado.2000.0302

McLeroy, K., Bibeau, D., Steckler, A., \& Glanz, K. (1988). An ecological perspective on health promotion programs. Health Education Quarterly, 15, 351-377. doi: 10.1177/109019818801500401

Merzel, C., \& D'Affilitti, J. (2003). Reconsidering community-based health promotion: Promise, performance, and potential. American Journal of Public Health, 93(4), 557-574. doi: 10.2105/AJPH.93.4.557

Michael, S. L., Merlo, C. L., Basch, C. E., Wentzel, K. R., \& Wechsler, H. (2015). Critical connections: Health and academics. Journal of School Health, 85(11), 740-758. doi: 10.1111/josh.12309

Millstein, R. A., \& Sallis, J. F. (2011). Youth advocacy for obesity prevention: The next wave of social change for health. Translational Behavioral Medicine, 1, 497-505. doi: 10.1007/s13142-011-00600

Moore, K. (2017). Commentary: Positive youth development goes mainstream. Child Development, 88(4), 1175-1177. doi: $10.1111 /$ cdev. 12874

National 4-H Council. (n.d.). What is 4-H? Retrieved from https://4-h.org/about/what-is-4-h/

Park, N. (2004). The role of subjective well-being in positive youth development. The ANNALS of the American Academy of Political and Social Science, 591(1), 25-39. doi: $10.1177 / 0002716203260078$

Pittman, K. J., Irby, M., Tolman, J., Yohalem, N., \& Ferber, T., (2003). Preventing problems or promoting development: Competing priorities or inseparable goals? Washington, DC: The Forum for Youth Investment. Retrieved from http://forumfyi.org/content/preventing-problems-pr

Proctor, C. L., \& Linley, P. A. (2014). Life satisfaction in youth. In G. A. Fava \& C. Ruini (Eds.), Increasing psychological well-being in clinical and educational settings: Cross-cultural advances in positive psychology (pp. 199-215). New York: Springer.

Proctor, C. L., Linley, P. A., \& Maltby, J. (2009). Youth life satisfaction: A review of the literature. Journal of Happiness Studies, 10, 583-630. doi: 10.1007/s10902-008-9110-9 
Journal of Youth Development | http://jyd.pitt.edu/ | Vol. 13 Issue 3 DOI 10.5195/jyd.2018.678

Health, Well-Being, and Youth Development

Raphael, D. (2013). Adolescence as a gateway to adult health outcomes. Maturitas, 75, 137-141. doi: 10.1016/j.maturitas.2013.03.013

Richard, L., Gauvin, L., \& Raine, K. (2011). Ecological models revisited: Their uses and evolution in health promotion over two decades. Annual Reviews of Public Health, 32, 307-326. doi:

10.1146/annurev-publhealth-031210-101141

Roth, J. L., \& Brooks-Gunn, J. (2016). Evaluating youth development programs. Applied Developmental Science, 20(3), 188-202. doi: 10.1080/10888691.2015.1113879

Sallis, J. F., \& Owen, N. (2015). Ecological models of health behavior. In K. Glanz, B. K. Rimer, \& K. Viswanath (Eds.), Health behavior: Theory, research, and practice (5th ed., pp. 43-64). San Francisco, CA: Jossey-Bass.

Sawyer, S. M., Afifi, R. A., Bearinger, L. H., Blakemore, S., Dick, B., Ezeh, A. C., \& Patton, G. C. (2012). Adolescence: A foundation for future health. The Lancet, 379, 1630-1640. doi: 10.1016/S01406736(12)60072-5

Sieving, R. E., McRee, A., McMorris, B. J., Shlafer, R. J., Grower, A. L., Kapa, H. M., . . Resnick, M. D. (2017). Youth-adult connectedness: A key protective factor in adolescent health. American Journal of Preventative Medicine, 52 (3S3), S275- S278. doi: 10.1016/j.amepre.2016.07.037

Smathers, C., Washburn, L., Toomey, M., Johannes, E., Iaccopucci, A. M., \& Johnston, K. (2018). Organizational readiness to engage in policy, system, and environment changes supporting positive youth development for health: Case studies from the Cooperative Extension System framed by the transtheoretical model. Journal of Human Science in Extension, 6(2), 81-101. Retrieved from https://docs. wixstatic.com/ugd/c8fe6e_4952100d71eb47f0ad4ea97fb3f380d7.pdf

Smith, E. P., Witherspoon, D. P., \& Osgood, D. W. (2017). Positive youth development among diverse racial-ethnic children: Quality afterschool contexts as developmental assets. Child Development, 88(4), 1063-1078. doi: 10.1111/cdev.12870

Stokols, D. (1996). Translating social ecological theory into guidelines for community health promotion. American Journal of Health Promotion, 10(4), 282-298. doi: 10.4278/0890-1171-10.4.282

Wong, N. T., Zimmerman, M. A., \& Parker, E. A, (2010). A typology of youth participation and empowerment for child and adolescent health promotion. American Journal of Community Psychology, 46, 100-114. doi: 10.1007/s10464-010-9330-0

World Health Organization. (2002). World health report 2002: Reducing risks, promoting healthy life. Geneva, Switzerland: Author. Retrieved from http://www.who.int/whr/2002/en/

Yohalem, N., \& Wilson-Ahlstrom, A. (2010). Inside the black box: Assessing and improving quality in youth programs. American Journal of Community Psychology, 45, 350-357. doi: 10.1007/s10464010-9311-3 
Journal of Youth Development | http://jyd.pitt.edu/ | Vol. 13 Issue 3 DOI 10.5195/jyd.2018.678 Health, Well-Being, and Youth Development

Zullig, K. J., Valois, R. F., Huebner, E. S, Oeltman, J. E., \& Drane, J. W. (2009). Relationship between perceived life satisfaction and adolescents' substance abuse. Journal of Adolescent Health, 29, 279-288. doi: 10.1016/S1054-139X(01)00269-5 